\title{
Reduced performance of native infauna following recruitment to a habitat-forming invasive marine alga
}

\author{
Paul E. Gribben $\mathbb{}$ Jeffrey T. Wright $\mathbb{}$ \\ Wayne A. O’Connor \& Martina A. Doblin \& \\ Bradley Eyre $\ell$ Peter D. Steinberg
}

\begin{abstract}
Despite well-documented negative impacts of invasive species on native biota, evidence for the facilitation of native organisms, particularly by habitat-forming invasive species, is increasing. However, most of these studies are conducted at the population or community level, and we know little about the individual fitness consequences of recruitment to habitat-forming invasive species and, consequently, whether recruitment to these habitats is adaptive. We determined the consequences of recruitment to the invasive green alga Caulerpa taxifolia on the native soft-sediment bivalve Anadara trapezia and nearby unvegetated sediment. Initially, we documented the growth and survivorship of A. trapezia following a natural recruitment event, to which recruitment to $\mathrm{C}$. taxifolia was
\end{abstract}

Communicated by Tony Underwood.

P. E. Gribben $(\boldsymbol{\&}) \cdot$ M. A. Doblin

Department of Environmental Sciences,

University of Technology, Sydney, NSW 2007, Australia

e-mail: paul.gribben@uts.edu.au

J. T. Wright

Institute for Conservation Biology and School of Biological

Sciences, University of Wollongong, Wollongong, NSW 2522,

Australia

W. A. O’Connor

NSW Department of Primary Industries Port Stephens Fisheries

Centre, Taylors Beach, NSW 2316, Australia

B. Eyre

School of Environmental Science and Management, Southern

Cross University, Lismore, NSW 2480, Australia

P. D. Steinberg

Centre for Marine Biofouling and Bio-Innovation and School of Biological, Earth and Environmental Sciences, University of New South Wales, Sydney, NSW 2052, Australia very high. After 12 months, few clams remained in either habitat, and those that remained showed little growth. Experimental manipulations of recruits demonstrated that all performance measures (survivorship, growth and condition) were significantly reduced in $\mathrm{C}$. taxifolia sediments compared to unvegetated sediments. Exploration of potential mechanisms responsible for the reduced performance in C. taxifolia sediments showed that water flow and water column dissolved oxygen (DO) were significantly reduced under the canopy of $\mathrm{C}$. taxifolia and that sediment anoxia was significantly higher and sediment sulphides greater in C. taxifolia sediments. However, phytoplankton abundance (an indicator of food supply) was significantly higher in C. taxifolia sediments than in unvegetated ones. Our results demonstrate that recruitment of native species to habitat-forming invasive species can reduce growth, condition and survivorship and that studies conducted at the community level may lead to erroneous conclusions about the impacts of invaders and should include studies on life-history traits, particularly juveniles.

Keywords Anadara trapezia - Bivalve ·

Caulerpa taxifolia · Fitness · Growth - Invasion biology ·

Juveniles · Maladaptive · Soft sediment · Survivorship

\section{Introduction}

Invasive species are one of the greatest threats to biodiversity and ecosystem function globally (Vitousek et al. 1996; Mack et al. 2000). Accordingly, studies on biological invasions have focussed almost exclusively on the direct negative impacts of non-native species (e.g. through competition and predation) on invaded ecosystems and biodiversity. For habitat-forming marine invasive species, 
negative impacts on native biota have also been linked to modification of the abiotic and biotic environment associated with invasion (e.g. water flow, food availability, sedimentation, light irradiance and physical and chemical sediment properties) (Neira et al. 2005, 2006; Hacker and Dethier 2006). However, there is emerging recognition that invasive species can have positive as well as negative effects (see Rodriguez 2006 and references therein). In soft-sediment environments, studies show a higher diversity and abundance of native biota in a range of habitatforming invasive species compared than in nearby unvegetated substrata (e.g. gastropods, mussels, seaweed, seagrass and salt-marsh) (Posey 1988; Crooks 1998, 2002; Wonham et al. 2005; Gribben and Wright 2006a).

Natural selection should act on habitat choice such that recruitment is adaptive. Although we can find no explicit statement to the fact, for those species that are facilitated by habitat-forming invasive species, the implication is that recruitment to these habitats is adaptive. However, there is a rich history of studies that demonstrate that organisms do make poor, or maladaptive, habitat choices that reduce individual fitness (see Robertson and Hutto 2006 for review). Negative impacts on life-history traits of marine organisms resulting from poor habitat choice have been demonstrated for several taxa, particularly invertebrates with complex life cycles in which the dispersive or larval stage is responsible for 'choosing' a habitat to begin the adult life-history stage. For example, settlement of the barnacle Chthamalus stellatus amongst another barnacle Balanus balanoides resulted in high mortality of newly settled recruits and the exclusion of C. stellatus from the low intertidal area (Connell 1961). Similarly, preferential settlement of the sea urchin, Holopneustes purpurascens on the poor quality host alga, Delisea pulchra, results in reduced fitness unless the former can move to a better quality host (Swanson et al. 2004; Williamson et al. 2004). Given the strong negative impacts that habitat-forming invasive species can have on the habitats they invade, particularly in soft-sediment marine environments, and the fact that life-history traits of marine invertebrates are sensitive to environmental change (Keck et al. 1975; Carmichael et al. 2004), we may also expect large negative effects on the life-history traits of native biota that recruit to these habitats.

Life-history theory predicts that individual fitness will be more sensitive to changes in the mortality, growth and fecundity of younger/smaller individuals (Stearns 1992). As such, studies investigating the effects of environmental change on native biota, such as those driven by habitatforming invasive species, need to incorporate studies on early life-history stages. However, most studies that investigate facilitation by habitat-forming invasive marine species have been conducted at the community level (Posey 1988; Crooks 1998; Hedge and Kriwoken 2000; Castilla et al.
2004; Wonham et al. 2005; Gribben and Wright 2006a). To date, no studies in the marine environment have addressed the potential negative effects on life-history traits of recruitment to habitat-forming invasive species and, therefore, we know little about whether recruitment to these habitats can be considered to be adaptive.

Since being discovered in 2000, the invasive green alga, Caulerpa taxifolia (Vahl) C. Agardh, has invaded 14 estuaries in southeastern Australia. Caulerpa taxifolia rapidly colonises unvegetated soft-sediments to form a thick complex structure (Wright 2005; Wright and Davies 2006) which modifies chemical and physical sediment properties (Chisholm and Moulin 2003). Although it outperforms native seagrasses (Ceccherelli and Cinelli 1997), seagrass beds in southeastern Australia may be relatively resistant to C. taxifolia invasion (Glasby and Creese 2007). Recent studies demonstrate that $C$. taxifolia enhances the recruitment of the native soft-sediment bivalve, Anadara trapezia (Gribben and Wright 2006a), but has negative effects on the abundance and life-history traits of adults compared to native seagrasses and unvegetated sediments (Gribben and Wright 2006b; Wright et al. 2007). This suggests that recruitment to $C$. taxifolia may be maladaptive and result in negative effects on life-history traits that act to reduce fitness.

Here we build on previous research and investigate whether positive effects on the recruitment of A. trapezia by C. taxifolia are maintained in life-history stages following recruitment. First, we followed a natural recruitment event and estimated changes in the abundance and size of recruits in invaded and unvegetated habitats over 12 months to infer consequences for survivorship and growth. Second, because recruits frequently occur on adult A. trapezia we also monitored the number of recruits on adult clams from the same habitats over the same time period. Third, we experimentally determined the effects of invaded and unvegetated habitats on key performance traits (survivorship, growth and condition) after 17 months of recruits transplanted into each habitat. In addition, we investigated potential mechanisms by which $C$. taxifolia may impact on native infauna by determining whether differences in key environmental characteristics (e.g. water flow, food supply and, sediment and water quality) exist between invaded and unvegetated habitats.

\section{Methods}

Species and study location

Detailed descriptions of the organisms and study sites can found in Gribben and Wright (2006a,b) and Wright et al. (2007). We present only brief descriptions here. Caulerpa 
taxifolia has invaded several temperate regions worldwide where it covers large areas of soft-sediment habitat and forms high density beds (Meinesz et al. 2001; Creese et al. 2004; Anderson 2005; Wright 2005) and modifies chemical and physical sediment properties (Chisholm and Moulin 2003). Reports on the response of native biota (e.g. seagrass, infaunal bivalves, fish and epibiota on hardsubstrata) to C. taxifolia appear to be largely negative (Bellan-Santini et al. 1996; Ceccherelli and Cinelli 1997; Levi and Francour 2004; Longepierre et al. 2005; Gribben and Wright 2006b; York et al. 2006; Wright et al. 2007), with the exception of positive effects on A. trapezia recruitment (Gribben and Wright 2006a).

The ark shell, A. trapezia, commonly known as the Sydney cockle, is a dioecious free-spawning bivalve found from Victoria to southern Queensland (Edgar 2000). Anadara trapezia is generally estuarine, occurring from the intertidal to shallow subtidal (water depth 0-2 m) in sheltered mud, sand and seagrass habitats. It can reach a shell length of $75 \mathrm{~mm}$ (Edgar 2000), and populations are dominated by individuals [45 mm (Wright et al. 2007). Anadara trapezia are epifaunal as recruits and infaunal as adults (Gribben and Wright 2006a; Wright et al. 2007).

All data were collected from Sponge Bay and Yooralla Bay in Lake Conjola $\left(35^{\circ} 15^{0} 44.3^{00} \mathrm{~S}, 150^{\circ} 26^{0} 47.8^{00} \mathrm{E}\right)$, a temperate barrier estuary in southeastern New South Wales. Caulerpa taxifolia was first described from Lake Conjola in 2000, but it may have been present for several years previous (Creese et al. 2004). Although several native seaweeds inhabit Lake Conjola, C. taxifolia is the most abundant macrophyte. In Lake Conjola and several other estuaries in southeastern New South Wales, C. taxifolia commonly invades soft-sediments inhabited by A. trapezia (Wright et al. 2007).

\section{Abundance and size of recruits following a natural settlement event}

We examined changes in the abundance and size of recruits for 1 year (from April 2005 to April 2006) following a large natural recruitment event of juvenile A. trapezia in Lake Conjola which occurred prior to April 2005 (Gribben and Wright 2006a). We sampled three habitats in both Yooralla Bay and Sponge Bay: sparse (30\% cover) and dense (100\% cover) C. taxifolia, and unvegetated sediments. Sampling was conducted on five occasions: 16 April, 23 July, 22 September, 25 November 2005 and 15 April 2006. Samples were collected haphazardly at water depths of 1.5-2 $\mathrm{m}$ from several intermingled patches of $C$. taxifolia and unvegetated habitats throughout each bay to reduce confounding spatial effects. This spatial design applies to all mensurative and experimental data collected. Although the seagrasses Zostera capricorni and Halophila ovalis are also found fringing the bays, they were not sampled in this survey as both seagrasses are sparse, and few bivalves recruit to these habitats in Lake Conjola (Gribben and Wright 2006a). On each sampling occasion at each habitat, ten replicate cores (diameter $22.5 \mathrm{~cm}$ ) were haphazardly pushed $10 \mathrm{~cm}$ into the sediment. For both the sparse and dense C. taxifolia habitats, the alga was initially removed from the core and placed into plastic bags. Although A. trapezia are epifaunal as recruits, we considered it important to also sample sediments for the presence of juveniles in case they move to this habitat as they grow. Thus, for all habitats, the top 3-5 cm of sediment were also removed from the cores and placed into a separate plastic bag. Sediment samples were washed through a 500Im sieve on site, and the number of recruits recorded. Caulerpa taxifolia samples were transported back to the University of New South Wales and searched for recruits. The number of recruits in each sample was recorded and the shell length (anterior-posterior axis of the right valve) of all recruits determined using video image analysis (Abramoff et al. 2004).

A two-factor analysis of variance (ANOVA) was used to test the effects of habitat (fixed) and site (random) on the abundance and size of recruits at the final sampling time only. We did not examine the factor time in this analysis as we were primarily interested in understanding the abundance of recruits 12 months after the recruitment event, not the patterns of recruit abundance through time. Only sparse and dense C. taxifolia were included in the analysis of final size as no recruits were recovered from unvegetated sediments. For all analyses, assumptions were checked by examining the distributions of residuals and plots of residuals versus means (Quinn and Keough 2002). Nonsignificant interaction terms in ANOVAs were removed if P $[0.25$ (Underwood 1997). Abundance data were $\mathrm{H}(\mathrm{X}$ ? 1) transformed. Student-Newman-Keuls (SNK) tests were used to test for differences among habitats when the factor habitat was significant.

Occurrence of juveniles on adults

Recruits have shown a preference for adult A. trapezia in habitat choice assays, and high numbers of recruits have been found attached to the shells of live adult A. trapezia postsettlement in C. taxifolia invaded sediments compared to those in unvegetated sediments (Gribben and Wright 2006a). We determined the abundance of recruits on adults over time to investigate evidence for recruits occurring in C. taxifolia secondarily recruiting to adults in C. taxifolia (no distinction was made between sparse and dense C. taxifolia) or adults in nearby unvegetated habitats. The number of recruits attached to adults (shell length [50 mm) was determined by haphazardly sampling adults $[\mathrm{n}=37-91$ depending on habitat and sampling conditions (e.g. visibility)] from both habitats 
at each site on each of the five sampling occasions described above. Because a high number of clams had no recruits attached ([ $86 \%$ of clams pooled from last three sampling times), the abundance of recruits on adults in both habitats was explored graphically only.

Effect of C. taxifolia and unvegetated sediment on recruit performance

Fitness depends on key traits, such growth, survivorship and fecundity (Stearns 1992; Crone 2001). Here we determine the effect of C. taxifolia on the survivorship, growth and condition of $\mathrm{A}$. trapezia recruits. Wet tissue biomass is used as a condition index and a surrogate for reproduction as histological analyses revealed that all clams at the end of the experiment (i.e. after 17 months) were still immature (data not shown).

Recruits were produced by the New South Wales Department of Primary Industries Port Stephens Fisheries Centre using standard bivalve culture techniques (Nell et al. 1994; Patterson and Nell 1996). Post-settlement individuals were maintained in mesh bags (standard scallop lantern nets $30930 \mathrm{~cm}$, mesh size $1 \mathrm{~mm}^{2}$ ) hung from oyster leases in Port Stephens until the start of the experiment. On the day the experiment commenced (i.e. 3 months post-settlement), mesh bags with recruits were collected from the racks, wrapped in cloth and transported on ice to Lake Conjola. Recruits ( $n=40$ /cage) were added to replicate lantern net cages ( $n=10 /$ habitat) which were placed into C. taxifolia and unvegetated sediments at Sponge Bay in May 2006. The initial size of the recruits [size range 12-15 mm shell length; mean shell length ( \pm standard error, SE) $12.43 \pm 0.14 \mathrm{~mm}$ ] was determined from 100 randomly sampled recruits at the beginning of the experiment. Two additional cages were placed into each habitat to serve as handling controls. We could not use uncaged controls due to high levels of predation on recruits in unvegetated sediments (Gribben and Wright 2006a). Survivorship and size (shell length) of all surviving recruits were determined after 1 month (June 2006), 3 months (August 2006), 6 months (November 2006), 8 months (January 2007), 12 months (May 2007) and 17 months (October 2007). Control cages were left undisturbed and only sampled at the end of the experiment (i.e. after 17 months). Individual wet tissue biomass was obtained at the end of the experiment by opening the clams with a small knife, removing all tissues, blotting them with a paper towel to remove excess water and then weighing. Wet tissue weights were obtained for all clams recovered in C. taxifolia and ten randomly selected clams from each mesh bag recovered from unvegetated sediments $(n=11$ bags; 110 clams in total).

Because of the non-independence of sampling through time and the fact that we were primarily interested in habitat effects on final size (shell length), we used a twofactor nested ANOVA to test the effects of habitat (fixed) and cage (random) nested within habitat on the final size of recruits. A t test was used to determine the effect of habitat on the percentage surviving in each cage at the end of the experiment. Because two control cages (one from each habitat) were not recovered at the end of the experiment, $t$ tests within habitats were used to test for the effects of handling by pooling experimental clams within each habitat and testing them against the shell length of clams in the appropriate control. Two-factor nested analyses of covariance (ANCOVA) were used to test the effects of habitat (fixed), cage (random) nested within habitat and final shell length (covariate) on wet tissue biomass.

Variation in environmental variables

between $\mathrm{C}$. taxifolia and unvegetated sediment

Changes in one or several of key biotic and abiotic environmental variables may have important implications for the fitness of biota. We quantified differences in water flow, water column dissolved oxygen (DO), sediment chemistry and food availability in C. taxifolia compared to unvegetated sediment. Unless otherwise stated, data were collected from Sponge Bay during February 2007.

\section{Relative water flow}

Differences in water flow between C. taxifolia and unvegetated sediments were investigated using the gypsum dissolution method (Doty 1971). Gypsum blocks work under the assumption that blocks dissolve differentially under different water flows so that the dissolution of gypsum per unit time (g/day) increases with increasing water flow (Doty 1971; Howerton and Boyd 1992; Thompson and Glenn 1994). Preweighed hemispherical gypsum blocks (approx. $7 \mathrm{~cm}$ in diameter $93.5 \mathrm{~cm}$ in height; approx. $59 \mathrm{~g}$ after 4 days of drying at $60^{\circ} \mathrm{C}$ ) were attached to Perspex plates $(10910 \mathrm{~cm})$ and fixed to stakes $(2095 \mathrm{~cm}$, length 9 diameter). Replicate stakes ( $n=10 /$ habitat) were then were pushed into the sediment in C. taxifolia invaded and unvegetated sediments so that the gypsum block faced up and the plate was flush with the sediment surface. Blocks were collected after 6 days, dried as described above and reweighed to determine percentage mass lost. A t test was used to investigate differences in water flow between habitats.

\section{Water column dissolved oxygen (DO)}

Differences in water column DO between C. taxifolia and unvegetated sediments were determined by collecting water samples using replicate $20 \mathrm{ml}$ syringes $(\mathrm{n}=10$ /habitat). Samples in both habitats were collected $3-5 \mathrm{~cm}$ above the 
sediment surface, immediately wrapped in foil and DO measured within 15 min of collection. DO was measured using oxygen-sensing 100-1m optodes (Precision Sensing). The optodes were calibrated linearly to $100 \%$ air saturation using methods outlined in Ulstrup et al. (2005). A t test was used to investigate differences in DO between habitats.

\section{Sediment chemistry}

Differences in pore water hydrogen sulphide $\left(\mathrm{H}_{2} \mathrm{~S}\right)$, acidvolatile sulphides (AVS), chromium-reducible sulphurs (CRS), sediment oxidation-reduction potential (ORP or redox) and $\mathrm{pH}$ between $\mathrm{C}$. taxifolia invaded and unvegetated sediments were investigated. High AVS/CRS ratios are indicative of increased anoxia. Replicate 200-ml sediment cores ( $\mathrm{n}=3$ /habitat) were collected from $\mathrm{C}$. taxifolia invaded and unvegetated sediments for analysis of $\mathrm{H}_{2} \mathrm{~S}$, AVS and CRS in March 2007 and transported to Southern Cross University, NSW. Each sediment core was extruded and sliced at 0-2, 6-8 and $13-15 \mathrm{~cm}$. One-half of each of the three sections was placed in a polyethylene tube and centrifuged at $2500 \mathrm{rpm}$ for $15 \mathrm{~min}$. The supernatant was fixed with zinc acetate (ZnAC) and analysed for $\mathrm{H}_{2} \mathrm{~S}$ (Cline 1969). All core extrusions, centrifugations and $\mathrm{ZnAC}$ additions were carried out in a nitrogen-filled glove bag. The concentrations of AVS and CRS were determined on the remaining half of each sediment interval using a two-step distillation method (Fossing and Jorgensen 1989; Sullivan et al. 2000). Separate cores ( $n=5 /$ habitat) were collected for analysis of redox and $\mathrm{pH}$ in May 2007 at a similar depth profile as described above. These cores were collected and taken back to shore where measurements were made immediately. Redox was measured using a Metrohm (Zofingen, Switzerland) AG 9109 Herisau Combined Ptwire electrode with $\mathrm{Ag} / \mathrm{AgCl}$ reference electrode and $\mathrm{Rex} \mathrm{pH}$ meter (Model pHb-4). The electrode was calibrated using Orion Application Solution ORP Standard 967961, and all redox readings were corrected for $\mathrm{E}_{\mathrm{H}}^{\mathrm{Ref}}=-210 \pm 3 \mathrm{mV}$, i.e. reported redox potentials relative to the hydrogen electrode, $\mathrm{E}_{\mathrm{H}}^{0}=0 \mathrm{mV}$. The $\mathrm{pH}$ was determined using a WTW 330i $\mathrm{pH}$ meter.

Three-factor ANOVAs were employed to determine the effect of habitat (fixed), sediment depth (fixed) and block (random) on $\mathrm{H}_{2} \mathrm{~S}$, AVS, CRS, the AVS:CRS ratio, redox and $\mathrm{pH}$. Because there is only one replicate of each habitat 9 depth combination within each core, there is no test for the factor block and interactions including the block factor (Quinn and Keough 2002).

\section{Relative food supply}

Differences in the abundance and diversity of phytoplankton communities between $\mathrm{C}$. taxifolia invaded and unvegetated sediments were investigated by collecting replicate $(n=4)$ 500-ml water samples $2 \mathrm{~cm}$ above the sediment from both habitats. Once collected, samples were fixed with Lugol's solution and transported back to the University of Technology (UTS), Sydney. To determine phytoplankton abundance, we examined the aliquots using an imaging flow cytometer (FlowCAM; Fluid Imaging Technologies, Yarmouth, ME) with a 209 objective and 100-1m flow cell. Samples were pumped at $0.2 \mathrm{ml} \mathrm{min}{ }^{-1}$, and the particles were monitored in "autoimaging" mode (recorded at a rate of 3 frames s$^{-1}$ ) and digital images of cells stored for analysis. The factory-provided calibration factors were used to calculate phytoplankton abundance in each of the samples. To identify phytoplankton, samples were settled (concentrating cells tenfold) before examination at 4009 magnification under an Olympus BX50 microscope fitted to a Leica DFC280 digital camera. Differences in the total abundance of phytoplankton and the abundance of large phytoplankton ([20 $\mathbf{I m})$ between habitats were investigated using $\mathrm{t}$ tests.

\section{Results}

Abundance and size of recruits following a natural settlement event

The initial mean abundance of recruits was higher in sparse and dense C. taxifolia sediments than in unvegetated sediments at both sites. However, after 12 months there were few recruits left in any habitat (Table 1, Fig. 1a). Nonetheless, there was a still a significant effect of habitat on final abundance, with a significantly higher abundance of recruits in the dense C. taxifolia habitat compared to the unvegetated habitat. There was no effect of site on final abundance. There no effect of habitaton the final shell length of recruits, but there was a slightly significant effect of site (Table 1, Fig. 1b). Overall, the size of recruits increased slightly over the year, indicating low growth (initial shell length range 2.12-8.05 mm; final shell length range $3.11-19.81 \mathrm{~mm}$ ) across habitats and sites.

\section{Occurrence of juveniles on adults}

Wide variations in the number of recruits/adult were observed throughout the study period. Initially, the number of recruits/adult was higher in C. taxifolia-invaded sediment than in unvegetated sediment. However, the number of recruits/adult in C. taxifolia sediments declined rapidly and by November 2005 (late spring), few recruits were present on adults in either habitat (Fig. 1c); only 2\% of adults sampled in unvegetated sediments and $20 \%$ of adults sampled in C. taxifolia sediments at the final sampling occasion had recruits attached. 
Table 1 Two-factor analyses of variance (ANOVA) for effect of site (random) and habitat (fixed) on the abundance of recruits in unvegetated habitats and dense and sparse Caulerpa taxifolia, and size (shell length) of recruits in dense and sparse C. taxifolia

\begin{tabular}{lrrrl}
\hline Source & df & \multicolumn{1}{c}{ MS } & F & P value \\
\hline Abundance & & & & \\
Site & 1 & 0.9976 & 0.28 & 0.6006 \\
Habitat & 2 & 12.4203 & 3.45 & $0.0388^{*}$ \\
Error & 54 & 3.5970 & & \\
SNK: DC โ UV, SC = DC, SC $=$ UV & & & \\
Size & & & & \\
Site & 1 & 42.8317 & 4.39 & $0.0479 *$ \\
Habitat & 1 & 5.9507 & 0.24 & 0.7112 \\
Site 9 Habitat depth & 1 & 25.0348 & 2.57 & 0.1235 \\
Error & 22 & 9.7593 & & \\
\hline
\end{tabular}

* P B 0.05. Student-Newman-Keuls (SNK) tests $(\mathrm{a}=0.05)$ were used to test for differences among habitats when the factor habitat was significant

UV, Unvegetated habitats; DC, SC dense and sparse C. taxifolia, respectively

Interactions where P [ 0.25 were removed from the models (Underwood 1997)

Effect of C. taxifolia and unvegetated sediment on recruit fitness

Final shell length $\left(\mathrm{F}_{1,16}=7.680, \mathrm{P} \backslash 0.014\right)$ and survivorship $\left(\mathrm{t}_{20}=5.679, \mathrm{P} \backslash 0.001\right)$ were both significantly lower in C. taxifolia sediment than in unvegetated sediment (Fig. 2a, b). There was a significant effect of cage, indicating spatial variation in growth within habitats $\left(F_{16,336}=3.281, P \backslash 0.001\right)$.

For each habitat there was no difference in final shell length of clams in the remaining control cage compared to treatment cages (clams pooled across all cages within habitats) (unvegetated sediments; pooled variance t-test, $\mathrm{t}=0.926, \mathrm{df}=274, \mathrm{P}=0.355 ; \mathrm{C}$. taxifolia sediments; pooled variance t-test, $\mathrm{t}=-0.845, \mathrm{df}=76, \mathrm{P}=0.200$ ), and survivorship in the control cages was comparable to those in the treatment cages in both habitats (unvegetated sediments range in treatment cage 37.5-92.5\%, control cage $47.5 \%$; C. taxifolia, range in treatment cage $0-52.5 \%$, control cage 35\%). Therefore, handling during the experiment did not appear to affect growth or survivorship.

For tissue biomass, there was a significant shelllength 9 habitat interaction (i.e. the assumption of homogeneity of slopes was not met, $F_{1,15}=10.889, P=0.005$ ), therefore we did not proceed with the ANCOVA. Although we could not test for a habitat effect, larger clams in unvegetated sediment appear to have greater tissue biomass relative to similar sized clams in C. taxifolia (Fig. 3).
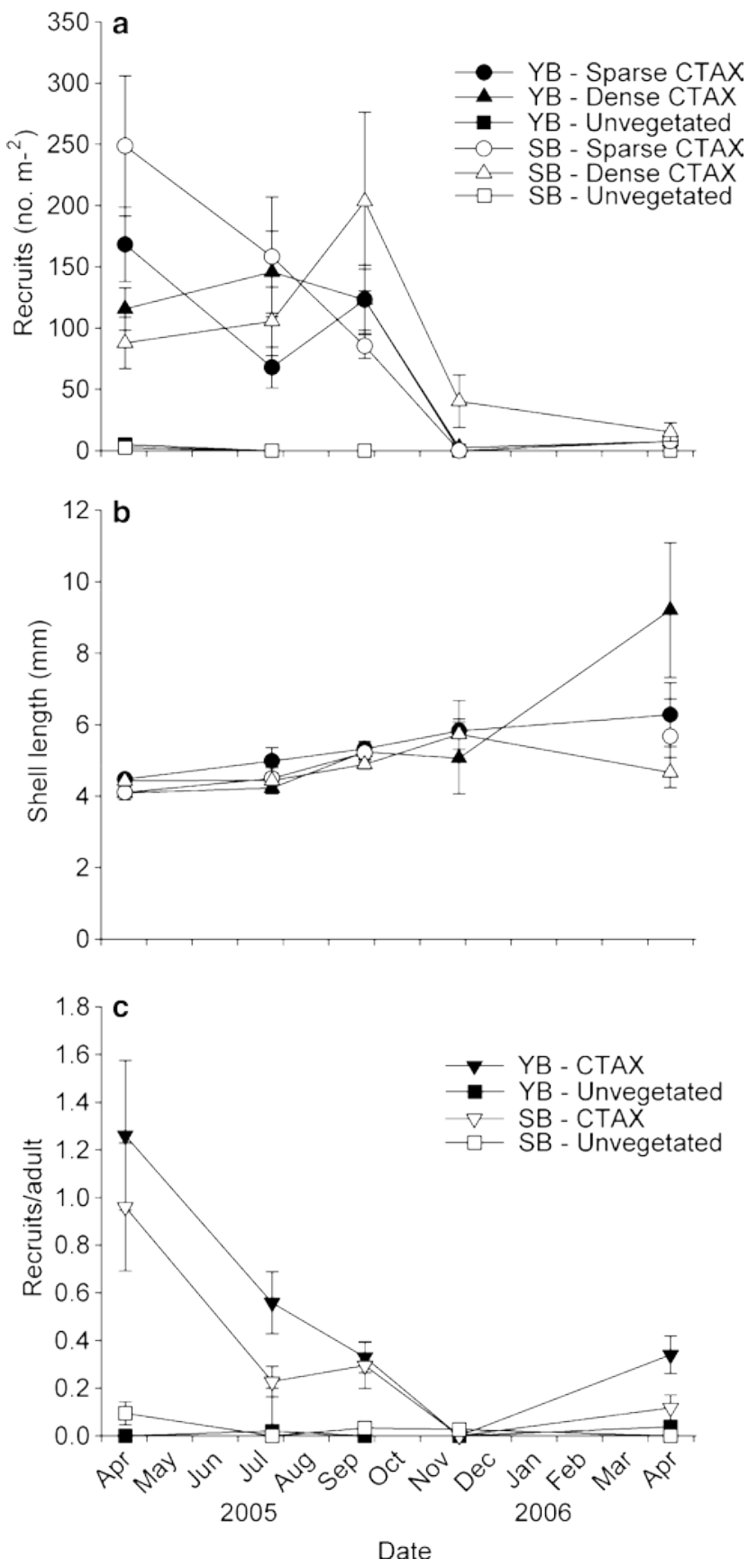

Fig. 1 Recruits and recruit characteristics of Sydney cockle (Anadara trapezia) sampled in three habitats of Sponge Bay (SB, open symbols) and Yooralla Bay (YB, solid symbols) in Lake Conjola, New South Wales from April 2005 to April 2006. a A. trapezia recruits (mean number $\mathrm{m}^{-2} \pm \mathrm{SE}, \mathrm{n}=10$ cores per habitat on each sampling date) in sparse (30\%, circles) or dense (100\%, triangles) Caulerpa taxifolia (CTAX) cover and in unvegetated sediments (squares). b Shell length (mean \pm SE, $n=6$-99 recruits per quadrat) in sparse and dense CTAX habitats. c A. trapezia recruits attached to shells of live A. trapezia adults (mean number of recruits per adult $\pm \mathrm{SE}$, $\mathrm{n}=31-53$ adults samples per site) in unvegetated sediments or sediments invaded by C. taxifolia (no distinction was made between sparse and dense CTAX population) 

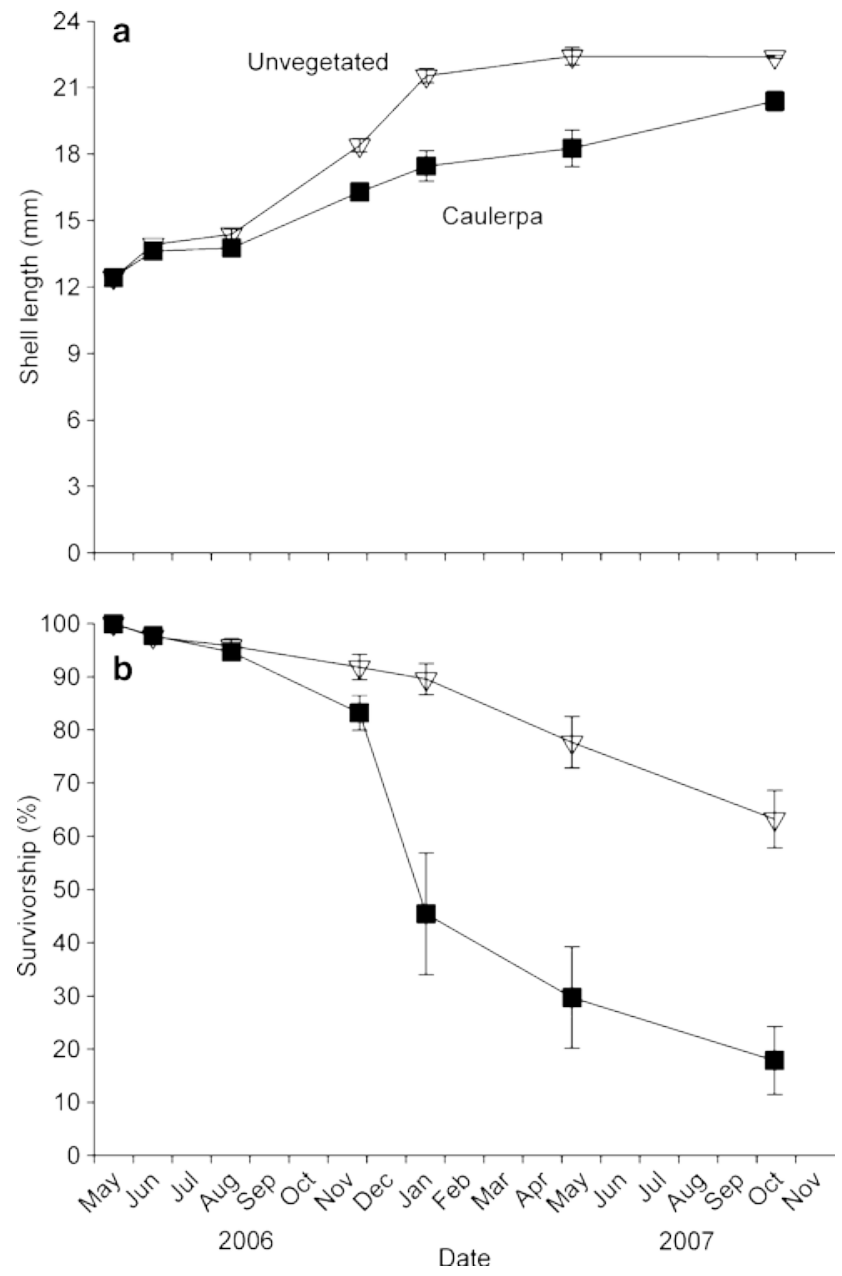

Fig. 2 Mean $( \pm \mathrm{SE})$ a shell length and b percent survivorship of recruits in cages $(n=10$ cages/habitat where each cage initially had 40 recruits) in C. taxifolia (filled squares) and unvegetated sediments (inverted triangles) in Sponge Bay, Lake Conjola from May 2006 to October 2007

Variation in environmental variables between

C. taxifolia and unvegetated sediments

\section{Relative water flow}

Percentage mass loss from gypsum blocks was significantly lower in C. taxifolia sediments than in unvegetated sediments (separate variance, $\mathrm{t}$ test, $\mathrm{t}_{10}=2.595, \mathrm{P}=0.02$ ), indicating reduced water flow within stands of C. taxifolia (Fig. 4a).

\section{Water column DO}

Water column DO was significantly lower in C. taxifolia sediments than in unvegetated sediments (separate variance, $\mathrm{t}$ test, $\mathrm{t}_{9}=5.696, \mathrm{P} \backslash 0.0001$ ) (Fig. $4 \mathrm{~b}$ ). Mean DO was $50 \%$ lower in $\mathrm{C}$. taxifolia sediments than in unvegetated sediments.

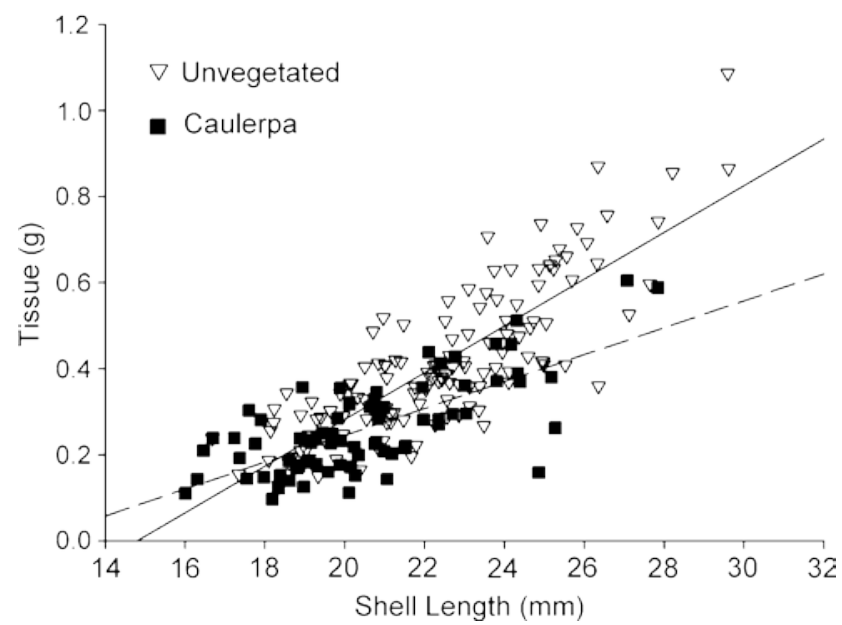

Fig. 3 Wet tissue weight versus shell length for recruits in cages in C. taxifolia invaded and unvegetated sediments in Sponge Bay, Lake Conjola from May 2006 to January 2007 ( $n=76$ and 109 recruits in total for C. taxifolia and unvegetated sediments, respectively). Caulerpa, $y=0.38 x$ ?0.03; $r^{2}=0.51$ (dashed line), unvegetated, $\mathrm{y}=-0.80 \mathrm{x}$ ? 0.05; $\mathrm{r}^{2}=0.67$ (solid line)

Sediment chemistry

There was a significant effect of habitat on CRS and redox, indicating increased anoxia in invaded sediments relative to unvegetated sediments (Fig. 4d, f; Table 2). $\mathrm{H}_{2} \mathrm{~S}$ and AVS values were also consistently higher, and $\mathrm{pH}$ consistently lower, in invaded sediments compared to unvegetated sediments, although the results were non-significant (Fig. 4c, e, g). There was a significant effect of depth on $\mathrm{pH}$ only.

Relative food supply

There were approximately twice as many cells in the C. taxifolia habitat than in the unvegetated sediments $\left(18.06 \pm 5.96910^{6}\right.$ vs. $7.07 \pm 2.00910^{6}$ cells l$^{-1}$; separate variance, $\mathrm{t}$ test, $\mathrm{t}_{4}=3.495, \mathrm{P}=0.029$ ). Phytoplankton in both habitats were dominated by small $(10 \mathrm{Im})$ cells, but large cells (e.g. pennate diatoms $\mathbf{\Gamma} 20 \mathbf{I m}$ ) were significantly more abundant in the C. taxifolia habitats than in the unvegetated habitat (Fig. 5; separate variance, $t$ test, $\left.\mathrm{t}_{4}=4.374, \mathrm{P}=0.007\right)$. The larger size fraction included diatom species, such as Pleurosigma directum, Nitzschia closterium, Striatella unipunctata, Pseudonitzschia sp. and Navicula sp., and the dinoflagellates Prorocentrum minimum and Prorocentrum gracile. Similar species were observed in each habitat (e.g. small centric diatoms, Pleurosigma directum, Pseudonitzschia sp., as shown in Fig. 5), but the diatom S. unipunctata formed ribbons rather than single cells amongst C. taxifolia, and long, needle-like pennate diatoms were relatively rare in unvegetated sediments. No potentially toxic species were found in either habitat. 
Fig. 4 Mean $( \pm \mathrm{SE})$ values for percentage loss of gypsum blocks (a), dissolved oxygen (DO) (b), hydrogen sulphide $\left(\mathrm{H}_{2} \mathrm{~S}\right)$ (c), chromium-reducible sulphides (CRS) (d), $\mathrm{pH}$ (e), sediment redox potential (redox) (f), acid-volatile sulphides (AVS) (g) at core depths of $0-2 \mathrm{~cm}$ (shallow), 6-8 cm (medium) and 13$15 \mathrm{~cm}$ (deep) collected from C. taxifolia (black bars) and unvegetated (grey bars) sediments in Sponge Bay, Lake Conjola during February 2007. Samples sizes $\mathrm{n}=10$ gypsum blocks/habitat and DO, $\mathrm{n}=3$ cores/habitat for $\mathrm{H}_{2} \mathrm{~S}$, CRS and AVS, $n=5$ for redox and $\mathrm{pH}$
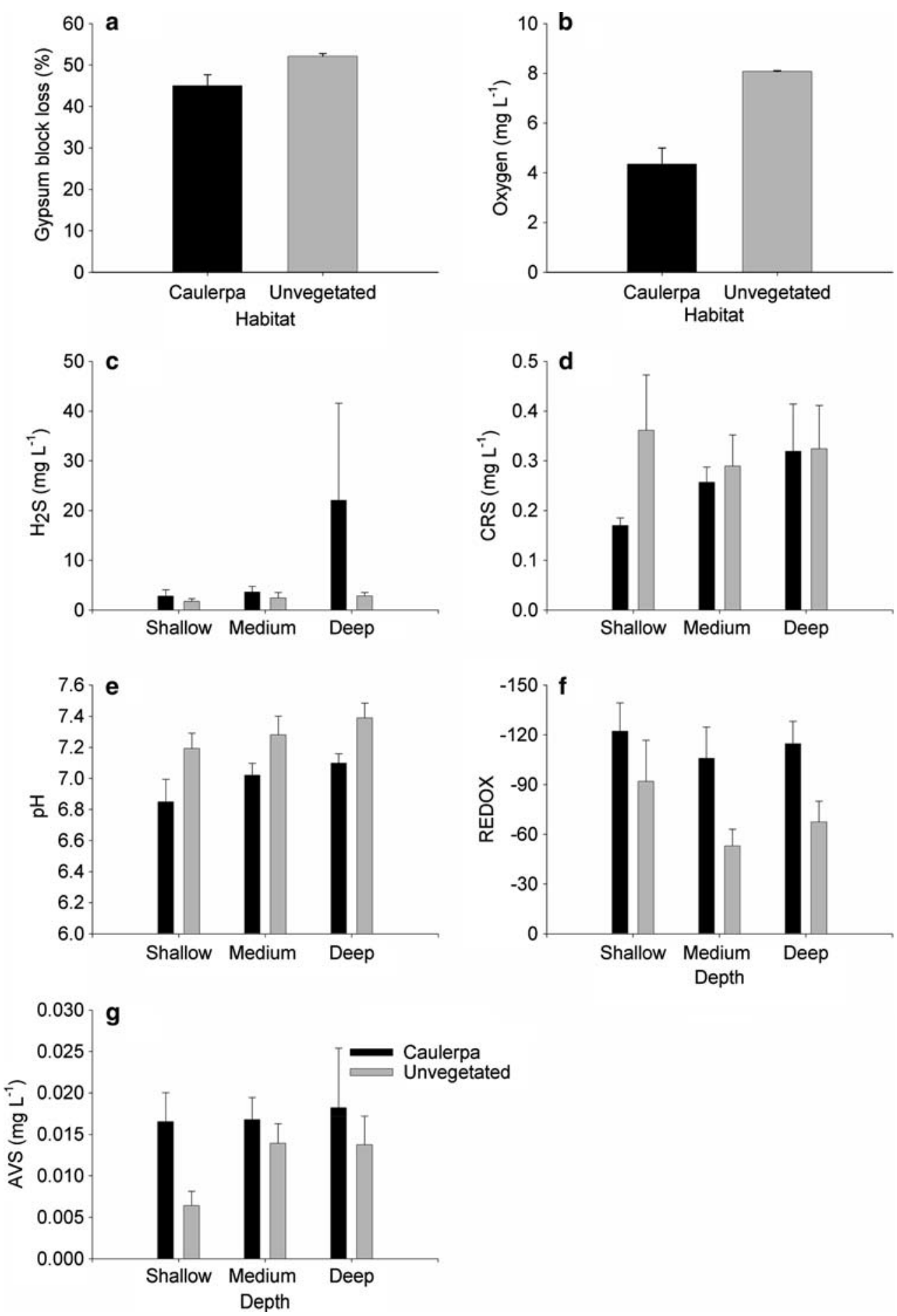

\section{Discussion}

By adding complexity to otherwise relatively open, unvegetated sediments, habitat-forming invasive species offer a settlement surface and protection from predation for native fauna. However, our data demonstrate that recruitment to habitat-forming invasive species is not always adaptive for these fauna, and such habitats can have strong negative impacts on key life-history traits of post- settlement individuals. Although the in situ monitoring of the A. trapezia recruitment event indicated similar low densities remained in both $\mathrm{C}$. taxifolia and unvegetated sediments after 1 year, our manipulative experiment demonstrated that $\mathrm{C}$. taxifolia reduces the growth, wet-tissue biomass and survivorship of A. trapezia that recruit to this habitat and, as such, individuals that survive in the invaded habitat are unlikely to contribute to population growth. Given that similar negative effects on reproduction, 
Table 2 Three factor ANOVAs for effect of habitat (fixed), sediment depth (fixed) and block (random) on hydrogen sulphide, acid-volatile sulphides, chromium-reducible sulphides, AVS:CRS ratio, sediment redox potential and $\mathrm{pH}$

\section{* P B 0.05}

DO, Dissolved oxygen; $\mathrm{H}_{2} \mathrm{~S}$, hydrogen sulphide; CRS, chromium-reducible sulphides; AVS, acid-volatile sulphides; redox, sediment redox potential Main effects terms and interactions including block are not shown as there is no test for these (Quinn and Keough 2002)

\begin{tabular}{|c|c|c|c|c|}
\hline Source & df & MS & $\mathrm{F}$ & $\mathrm{P}$ value \\
\hline \multicolumn{5}{|l|}{$\mathrm{H}_{2} \mathrm{~S}$} \\
\hline Habitat & 1 & 229.908 & 1.4092 & 0.357 \\
\hline Habitat 9 block (Residual 1) & 2 & 163.147 & & \\
\hline Depth & 2 & 173.423 & 0.8130 & 0.505 \\
\hline Depth 9 block (Residual 2) & 4 & 213.297 & & \\
\hline Habitat 9 depth & 2 & 161.035 & 0.8116 & 0.506 \\
\hline Habitat 9 depth 9 block (Residual 3) & & 198.405 & & \\
\hline \multicolumn{5}{|l|}{ AVS } \\
\hline Habitat & 1 & 0.000152 & 1.9875 & 0.294 \\
\hline Habitat 9 block (Residual 1) & 2 & 0.000077 & & \\
\hline Depth & 2 & 0.000036 & 0.6087 & 0.588 \\
\hline Depth 9 block (Residual 2) & 4 & 0.000058 & & \\
\hline Habitat 9 depth & 2 & 0.000021 & 3.6211 & 0.1266 \\
\hline Habitat 9 depth 9 block (Residual 3) & 4 & 0.000007 & & \\
\hline \multicolumn{5}{|l|}{ CRS } \\
\hline Habitat & 1 & 0.0263 & 35.5363 & $0.027^{*}$ \\
\hline Habitat 9 block (Residual 1) & 2 & 0.00074 & & \\
\hline Depth & 2 & 0.00558 & 0.6116 & 0.587 \\
\hline Depth 9 block (Residual 2) & 4 & 0.00909 & & \\
\hline Habitat 9 depth & 2 & 0.01513 & 0.405 & 0.692 \\
\hline Habitat 9 depth 9 block (Residual 3) & 4 & 0.03736 & & \\
\hline \multicolumn{5}{|l|}{ AVS:CRS } \\
\hline Habitat & 1 & 0.0042 & 3.2122 & 0.215 \\
\hline Habitat 9 block (Residual 1) & 2 & 0.0013 & & \\
\hline Depth & 2 & 0.0002 & 0.207 & 0.821 \\
\hline Depth 9 block (Residual 2) & 4 & 0.0088 & & \\
\hline Habitat 9 depth & 2 & 0.0025 & 0.5983 & 0.593 \\
\hline Habitat 9 depth 9 block (Residual 3) & 4 & 0.0010 & & \\
\hline \multicolumn{5}{|l|}{ Redox } \\
\hline Habitat & 1 & 14126.7 & 13.15 & $0.021^{*}$ \\
\hline Habitat 9 block (Residual 1) & 4 & 3316.7 & & \\
\hline Depth & 2 & 1935.1 & 1.515 & 0.277 \\
\hline Depth 9 block (Residual 2) & 8 & 1277.5 & & \\
\hline Habitat 9 depth & 2 & 346.3 & 0.430 & 0.665 \\
\hline Habitat 9 depth 9 block (Residual 3) & 8 & 804.9 & & \\
\hline \multicolumn{5}{|l|}{$\mathrm{pH}$} \\
\hline Habitat & 1 & 0.666 & 3.469 & 0.136 \\
\hline Habitat 9 block (Residual 1) & 4 & 0.192 & & \\
\hline Depth & 2 & 0.125 & 17.923 & $0.001^{*}$ \\
\hline Depth 9 block (Residual 2) & 8 & 0.007 & & \\
\hline Habitat 9 depth & 2 & 0.005 & 0.302 & 0.747 \\
\hline Habitat 9 depth 9 block (Residual 3) & 8 & 0.015 & & \\
\hline
\end{tabular}

somatic tissue and shell traits, and scaling relationships between these traits have been documented for adult A. trapezia in C. taxifolia sediments compared to unvegetated sediments (Gribben and Wright 2006b; Wright et al. 2007; Wright and Gribben 2008), we suggest that recruitment to $\mathrm{C}$. taxifolia will have strong negative impacts on the future reproductive success of A. trapezia and, therefore, on its individual fitness. However, understanding the effects of $\mathrm{C}$. taxifolia on reproductive traits and how changes in scaling relationships in juveniles affect 


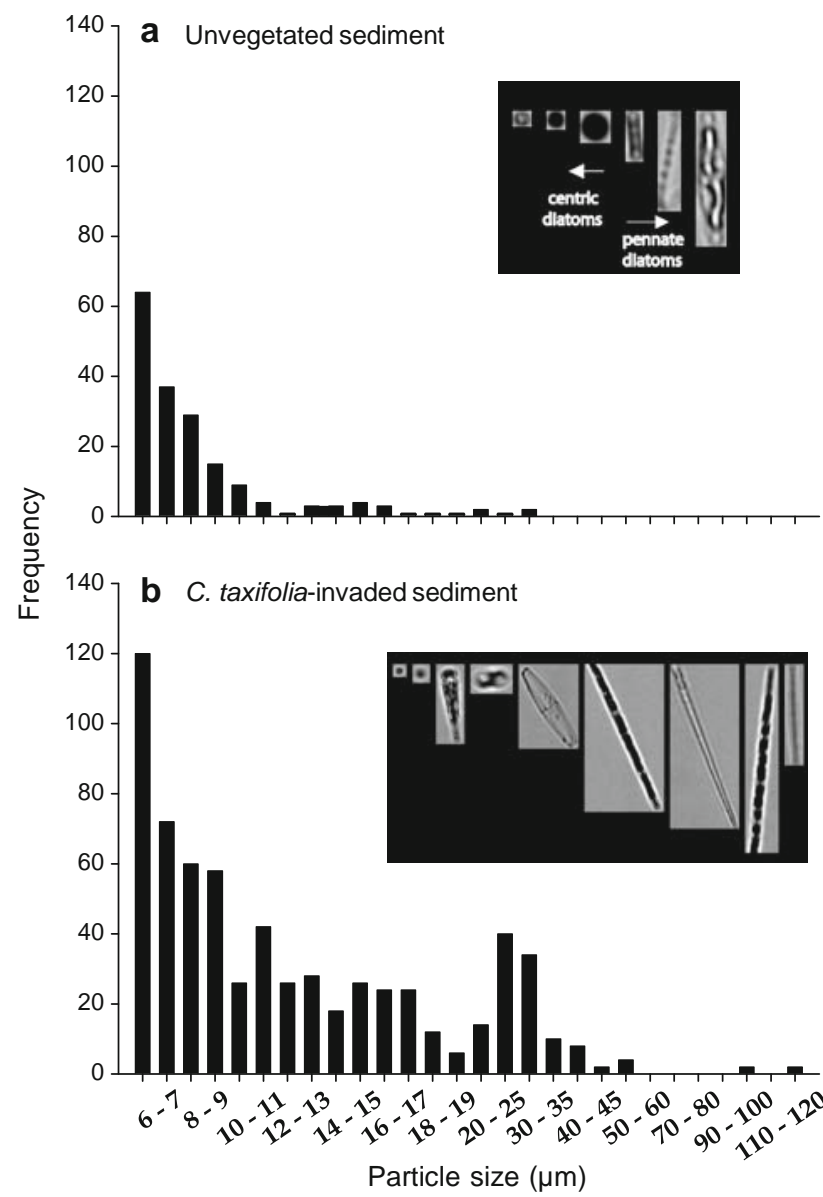

Fig. 5 Particle size distribution in water collected above unvegetated (a) and C. taxifolia-invaded (b) sediments. Insets show representative particles of increasing equivalent spherical diameter. Small centric diatoms were common in both samples, as were larger pennate diatoms, such as Pleurosigma directum and Pseudonitzschia sp. (left to right in inset images, respectively)

sexual development (e.g. sex ratios, age/size at sexual maturity, fecundity) will be an important avenue for future research.

The importance of autogenic properties of habitatforming invasive species (e.g. additional habitat complexity) in facilitating biota has been demonstrated (Crooks 1998; Crooks and Khim 1999). However, allogenic properties (e.g. the ability to alter sediment chemistry, water flow and food availability) of habitat-forming invasive species also have strong negative impacts on associated organisms (Levin et al. 2006). For example, the alteration of trophic function following invasion by a hybrid cordgrass had negative impacts on the biomass of suspension feeding bivalves compared to nearby unvegetated substrata (Levin et al. 2006). In addition, the native seagrass Zostera marina controlled the growth and survivorship of the invasive mussel, Musculista senhousia, which recruited to it, through limiting food supply (Reusch and Williams
1999; Allen and Williams 2003). However, for native macrophytes, positive effects on food supply have also been reported (Irlandi and Peterson 1991; Cummins et al. 2004). Although it is likely that phytoplankton populations are variable in space and time, the higher densities of phytoplankton in C. taxifolia invaded habitats than in unvegetated habitats indicate that food limitation is unlikely to explain negative effects on recruits in C. taxifolia-softsediment bivalves efficiently retain particles down to $7 \mathbf{~ I m}$ (Winter 1978), so the high abundance of phytoplankton in C. taxifolia sediments above this size indicates that potential food supply is higher in this habitat. No toxic or potentially toxic phytoplankton were found in either habitat that could explain negative impacts on clams.

The reduced performance of recruits in C. taxifolia sediments may be linked to the observed changes in sediment and/or water properties associated with C. taxifolia. Low dissolved oxygen and anoxia have been reported in macroalgal mats due to the respiration of the algae, decomposition of accumulated macroalgal detritus and low rates of photosynthesis below the canopy (D'Avanzo and Kremer 1994; Deegan et al. 2002). Reduced water flow in C. taxifolia sediments compared to unvegetated sediments may also have contributed to low DO, although C. taxifolia generally appears to colonise low-flow environments in estuaries in New South Wales (P.E. Gribben and J.T. Wright, personal observation). Both field and laboratory studies have demonstrated the negative impacts of low DO on estuarine biota (Breitburg 1992; Decker et al. 2003). Although we do not know the DO tolerance of A. trapezia, hypoxic conditions $\left(2.8 \mathrm{mg} \mathrm{O}_{2} \mathrm{l}^{-1}\right.$ ) can result in the high mortality of sessile invertebrates (Peterson and Estes 2001), with values higher than this potentially having sublethal effects on the physiology of soft-sediment bivalves (Malouf and Bricelj 1989). Significantly lower redox and higher levels of sulphides in C. taxifolia sediments compared to those in unvegetated areas may have contributed to the observed impacts on performance traits, although sediments in both habitats appear to be anoxic. In order to develop a full mechanistic understanding of the impacts of habitat-forming invasive species, manipulation of those environmental variables likely to be driving negative impacts on native biota is required (Neira et al. 2005). However, regardless of the potential mechanism, our novel finding of extensive hypoxia within the canopy of a habitatforming invasive species has broad implications for the fitness of epi- and infaunal organisms and, more generally, eco-system function.

Despite having negative effects on the life-history traits and the abundance of bivalves, recruitment to habitatforming invasive species may still contribute to population growth if the native species can secondarily recruit to good quality habitats (e.g. unvegetated sediment). Habitat choice 
assays have shown that A. trapezia recruits are mobile and gregarious and that they will move onto adults in preference to other available substrata including C. taxifolia (Gribben and Wright 2006a). However, the monitoring of recruits on adults from both habitats provided little indication of secondary recruitment occurring, with few recruits remaining on any substrata after 1 year. In several bays in which populations of A. trapezia occur, C. taxifolia is now the dominant habitat available for settlement, and there is little good quality habitat remaining. Given the negative impacts on key life-history traits of recruits (this study) and adults (Gribben and Wright 2006b; Wright and Gribben 2008) and the extent to which C. taxifolia has invaded the benthos in Lake Conjola, populations of A. trapezia invaded by C. taxifolia in this estuary are unlikely to persist. Moreover, the abundance and health of adult A. trapezia are reduced in sediments containing C. taxifolia compared to those with native seagrass and unvegetated sediments in multiple estuaries in southeastern New South Wales, suggesting that habitat-forming invasive species may impact on native organisms on a regional scale (Wright et al. 2007).

Interestingly, the growth rates of recruits on C. taxifolia were much lower than those in cages in $\mathrm{C}$. taxifolia. This could be an artifact of caging or temporal variations in growth rates (data were collected 1 year apart). However, it was more likely a result of the clams in cages being 6 months of age and between 12-15 mm in shell length when placed in this habitat-i.e. they had a previous, relatively long-term exposure to a good quality habitat. Negative impacts on recruits in C. taxifolia may be even more severe than on those older/larger recruits used in this study, although the small size of settled individuals $(300 \mathbf{~ I m}$ ) precluded us from using immediately settled individuals.

Given that A. trapezia recruits to C. taxifolia in high abundance and that there are large negative impacts on multiple traits of recruits and adults in C. taxifolia, C. taxifolia may be an ecological or evolutionary trap for A. trapezia. However, the final criteria for establishing the presence of an ecological trap, that of preferred or equal preference for a poor quality habitat (Robertson and Hutto 2006), is an important avenue for future research. Additionally, our caging experiment suggests that high recruitment to C. taxifolia may reflect a trade-off between predation risk and individual fitness. Unvegetated sediment is a higher quality habitat (i.e. higher growth of clams in unvegetated vs. invaded sediments) but has a higher predation risk (Gribben and Wright 2006a), whereas C. taxifoliainvaded sediments offer a lower risk of predation but are of poorer quality. The selection by mobile adult bivalves (e.g. scallops) for high-quality, high predation unvegetated habitats over lower predation, lower quality habitats (native seagrass) has been demonstrated (Bologna and Heck 1999).
One of the major aims of invasive species research is to develop models for predicting their impacts. As noted by Crooks (2002), an important question with regard to exotic habitat-forming species is whether they will have predictable effects when establishing in foreign ecosystems. Given the growing number of studies that demonstrate facilitation of species richness and population abundances via autogenic engineering by habitat-forming invasive species, the positive effects of these types of invaders may be a predictable outcome of invasion. However, lower growth and survivorship of recruits and a reduced fitness and abundance of adults (Crooks 2001, 2002; Gribben and Wright 2006b; Wright et al. 2007) through allogenic engineering may also be a predictable negative impact of habitat-forming invasive species. Furthermore, we suggest that studies conducted solely at the community level may underestimate the potential impacts of invasive species in soft-sediment ecosystems and that these studies should incorporate studies of fitness of associated fauna. The challenge remains to determine which environmental variables are responsible for the negative impacts on native infauna and, more importantly, what the net demographic effect of the conflicting autogenic and allogenic properties habitat-forming invasive species are for population growth of native infauna.

Acknowledgments We are grateful to Michael Clements for assistance with fieldwork and Louise McKenzie for assisting with fieldwork and video image analyses. Jeb Byers and two anonymous reviewers provided valuable comments which greatly improved the manuscript.

\section{References}

Abramoff MD, Magelhaes PJ, Ram SJ (2004) Image processing with ImageJ. Biophotonics Int 11:36-42

Allen BJ, Williams SL (2003) Native eelgrass Zostera marina controls growth and reproduction of an invasive mussel through food limitation. Mar Ecol Prog Ser 254:57-67

Anderson LW (2005) California's reaction to Caulerpa taxifolia: a model for invasive species rapid response. Biol Invasions 7:1003-1006

Bellan-Santini D, Arnaud P, Bellan G, Verlaque M (1996) The influence of the introduced alga, Caulerpa taxifolia, on the biodiversity of the Mediterranean marine biota. J Mar Biol Assoc UK 76:235-237

Bologna PAX, Heck KL (1999) Differential predation and growth rates of bay scallops within a seagrass habitat. J Exp Mar Bio Ecol 239:299-314

Breitburg DL (1992) Episodic hypoxia in Chesapeake Bay: interacting effects of recruitment, behavior, and physical disturbance. Ecol Monogr 62:525-546

Carmichael RH, Shriver AC, Valiela I (2004) Changes in shell and soft tissue growth, tissue composition, and survival of quahogs, Mercenaria mercenaria, and softshell clams, Mya arenaria, in response to eutrophic-driven changes in food supply and habitat. J Exp Mar Biol Ecol 313:75-104 
Castilla JC, Lagos NA, Cerda M (2004) Marine ecosystem engineering by the alien ascidian Pyura praeputialis on a mid-intertidal rocky shore. Mar Ecol Prog Ser 268:119-130

Ceccherelli G, Cinelli F (1997) Short-term effects of nutrient enrichment of the sediment and interactions between the seagrass Cymedocea nodosa and the introduced green alga Caulerpa taxifolia in a Mediterranean bay. J Exp Mar Biol Ecol 217:165-177

Chisholm JRM, Moulin P (2003) Stimulation of nitrogen fixation in refractory organic sediments by Caulerpa taxifolia (Chlorophyta). Limnol Oceanogr 48:787-794

Cline J (1969) Spectrophotometric determination of hydrogen sulfide in natural waters. Limnol Oceanogr 14:454-458

Connell JH (1961) The influence of interspecific competition and other factors on the distribution of the barnacle Chthamalus stellatus. Ecology 42:710-723

Creese RG, Davies AR, Glasby TM (2004) Eradicating and preventing the spread of the invasive alga Caulerpa taxifolia in NSW. NSW Fish Final Rep Ser 64:110

Crone EE (2001) Is survivorship a better surrogate than fecundity? Oikos 55:2611-2614

Crooks JA (1998) Habitat alteration and community-level effects of an exotic mussel, Musculista senhousia. Mar Ecol Prog Ser 162:137-152

Crooks JA (2001) Assessing invader roles within changing ecosystems: historical and experimental perspectives on an exotic mussel in an urbanized lagoon. Biol Invasions 3:23-36

Crooks JA (2002) Characterizing eco-system consequences of biological invasions: the role of ecosystem engineers. Oikos 97:137-152

Crooks JA, Khim HS (1999) Architectural vs. biological effects of a habitat-altering, exotic mussel, Musculista senhousia. J Exp Mar Biol Ecol 240:53-75

Cummins SP, Roberts DE, Ajani P, Underwood AJ (2004) Comparisons of assemblages of phytoplankton between open water and seagrass habitats in a shallow coastal lagoon. Mar Freshw Res 55:447-456

D’Avanzo C, Kremer JN (1994) Diel oxygen dynamics and anoxic events in an eutrophic estuary of Waquoit Bay, Massachusetts. Estuaries 17:131-139

Decker MB, Breitburg DL, Marcus NH (2003) Geographical differences in behavioral responses to hypoxia: local adaptation to an anthropogenic stressor? Ecol Appl 14:1104-1109

Deegan LA, Wright A, Ayvazian SG, Finn JT, Golden H, Rand Merson R, Harrison J (2002) Nitrogen loading alters seagrass ecosystem structure and support of higher trophic levels. Aquat Conserv Mar Freshw Ecosyst 12:193-212

Doty MS (1971) Measurements in water movement in reference to benthic algae growth. Bot Mar 14:32-35

Edgar GJ (2000) Australian marine life: the plants and animals of temperate waters. Reed New Holland, Sydney

Fossing H, Jorgensen BB (1989) Measurement of bacterial sulfate reduction in sediments: evaluation of single-step chromium reduction method. Biogeochemistry 8:205-222

Glasby TM, Creese RG (2007) Invasive marine species management and research. In: Connell SD, Gillanders BM (eds) Marine ecology. Oxford University Press, Melbourne, pp 569-594

Gribben PE, Wright JT (2006a) Invasive seaweed enhances recruitment of a native bivalve: roles of refuge from predation and habitat choice. Mar Ecol Prog Ser 318:177-185

Gribben PE, Wright JT (2006b) Sublethal effects on reproduction in native fauna: are females more vulnerable to biological invasion? Oecologia 149:352-361

Hacker SD, Dethier MN (2006) Community modification by a grass invader has differing impacts for marine habitats. Oikos 113:279-286
Hedge P, Kriwoken Lk (2000) Evidence for effects of Spartina anglica invasion on benthic macrofauna in Little Swanport Estuary, Tasmania. Austral Ecol 25:150-159

Howerton RD, Boyd CE (1992) Measurements of water circulation in ponds with gypsum blocks. Aquac Eng 11:141-155

Irlandi EA, Peterson CH (1991) Modification of animal habitat by large plants: mechanisms by which seagrasses influence clam growth. Oecologia 87:307-318

Keck RT, Maurer D, Lind H (1975) A comparative study of the hard clam gonad development cycle. Biol Bull 148:243-258

Levi F, Francour P (2004) Behavioural response of Mullus surmuletus to habitat modification by the invasive macroalga Caulerpa taxifolia. J Fish Biol 64:55-64

Levin LA, Neira C, Grosholz ED (2006) Invasive cordgrass modifies wetland trophic function. Ecology 87:419-432

Longepierre S, Robert A, Levi F, Francour P (2005) How an invasive alga species (Caulerpa taxifolia) induces changes in foraging strategies of the benthivorous fish Mullus surmuletus in coastal Mediterranean ecosystems. Biodivers Conserv 14:365-376

Mack RN, Simberloff D, Lonsdale WM, Evans H, Clout M, Bazzaz FA (2000) Biotic invasions: causes, epidemiology, global consequences, and control. Ecol Appl 10:689-710

Malouf RE, Bricelj VM (1989) Comparative biology of clams: environmental tolerances, feeding, and growth. In: Manzi J, Castagna M (eds) Clam mariculture in North America. Elsevier, Amsterdam, pp 23-73

Meinesz A, Belsher T, Thibaut T, Antolic B, Ben Mustapha K, Bourdouresque C-F, Chiaverini D, Cottalorda J-M, Djellouli A, El Abed A, Orestano C, Grau AM, Ivesa L, Jaklin L, Langar H, Massuti-Pascual E, Peirano A, Tunesi L, de Vaugelas J, Zavodnik N, Zuljevic A (2001) The introduced marine alga Caulerpa taxifolia in the Medtiterranean. Biol Invasions 38:499508

Neira C, Levin LA, Grosholz ED (2005) Benthic macrofaunal communities of three sites in San Francisco Bay invaded by hybrid Spartina, with comparison to uninvaded habitats. Mar Ecol Prog Ser 292:111-126

Neira C, Grosholz ED, Levin LA, Blake R (2006) Mechanisms generating modification of benthos following tidal flat invasion by a Spartina hybrid. Ecol Appl 16:1391-1404

Nell JA, O’Connor WA, Heasman MP, Goard LJ (1994) Hatchery production for the venerid clam Katelysia rhytiphora (Lamy) and the Sydney cockle Anadara trapezia (Deshayes). Aquaculture 119:149-156

Patterson K, Nell J (1996) Estuarine clam farming in NSW. Austasia Aquac 10:52-53

Peterson CH, Estes JA (2001) Conservation and management of marine communities. In: Bertness MD, Gaines SD, Hay ME (eds) Marine community ecology. Sinuaer, Sunderland, pp 469507

Posey MH (1988) Community changes associated with the spread of an introduced seagrass, Zostera japonica. Ecology 69:974-983

Quinn GP, Keough MJ (2002) Experimental design and data analysis for biologists. Cambridge University Press, Cambridge

Reusch TBH, Williams SL (1999) Macrophyte canopy structure and the success of an invasive marine bivalve. Oikos 84:398-416

Robertson BA, Hutto RL (2006) A framework for understanding ecological traps and an evaluation of existing evidence. Ecology 87:1075-1085

Rodriguez LF (2006) Can invasive species facilitate native species? Evidence of how, when, and why these impacts occur. Biol Invasions 8:927-939

Stearns SC (1992) The evolution of life histories. Oxford University Press, New York

Sullivan LA, Bush RT, McConchie DM (2000) A modified chromium-reducible sulfur method for reduced inorganic sulfur: 
optimum reaction time for acid sulfate soil. Aust J Soil Res 38:729-734

Swanson RL, Williamson JE, De Nys R, Kumar N, Bucknall MP (2004) Induction of settlement of larvae of the sea urchin Holopneustes purpurascens by histamine from its host plant. Biol Bull 206:161-172

Thompson TL, Glenn EP (1994) Plaster standards to measure water motion. Limnol Oceanogr 39:1768-1779

Ulstrup KE, Hill R, Ralph PJ (2005) Photosynthetic impact of hypoxia on in hospite zooxanthellae in the scleractinian coral Pocillopora damicornis. Mar Ecol Prog Ser 286:125-132

Underwood AJ (1997) Experiments in ecology. Cambridge University Press, Cambridge

Vitousek PM, D’Antonio CM, Loope LL, Westbrooks R (1996) Biological invasions as global environmental change. Am Sci 84:468-478

Williamson JE, Carson DG, De Nys R, Steinberg PD (2004) Demographic consequences of an ontogenetic shift by a sea urchin in response to host plant chemistry. Ecology 85:13551371

Winter JE (1978) A review of the knowledge of suspension-feeding in lamellibranchiate bivalves, with special reference to artificial aquaculture systems. Aquaculture 13:1-33
Wonham MJ, O’Connor M, Harley CDG (2005) Positive effects of a dominant invader on introduced and native mudflat species. Mar Ecol Prog Ser 289:109-116

Wright JT (2005) Differences between native and invasive Caulerpa taxifolia: a link between asexual fragmentation and abundance in invasive populations. Mar Biol 147:559-569

Wright JT, Davies AR (2006) Demographic feedback between clonal growth and fragmentation in an invasive seaweed. Ecology 87:1744-1754

Wright JT, Gribben PE (2008) Fitness response of fauna to an invasive seaweed: predictions of impact based on community structure alone are insufficient. J Appl Ecol 45:1540-1549

Wright JT, McKenzie LA, Gribben PE (2007) A decline in the density and health of a native bivalve associated with Caulerpa taxifolia invasion. Mar Freshw Res 58:263-277

York PH, Booth DJ, Glasby TM, Pease BC (2006) Fish assemblages in habitats dominated by Caulerpa taxifolia and native seagrasses in south-eastern Australia. Mar Ecol Prog Ser 312:223234 